\title{
The Training on Making Pinnate Leaves Cakes toward Housewives of Lahai Roi Congregation, Tofa
}

\section{Pelatihan Pembuatan Kue Basah Kelor bagi Kaum Ibu Jema'at Lahai Roi-Tofa}

\author{
Johnson N. Naat ${ }^{\mathrm{a}, *}$, Yosep Lawa ${ }^{\mathrm{a}}$, Yantus A. B. Neolaka ${ }^{\mathrm{a}}$, Dewi Lestarani ${ }^{\mathrm{a}}$, \\ Lolita A. M. Parera ${ }^{\mathrm{a}}$, Yanpitherzon Liunokas ${ }^{\mathrm{b}}$ \\ ${ }^{a}$ Program Studi Pendidikan Kimia, FKIP, Universitas Nusa Cendana-Kupang-NTT \\ ${ }^{b}$ Program Studi Pendidikan Bahasa Inggris, FKIP, Universitas Nusa Cendana-Kupang-NTT
}

\begin{abstract}
Marunggai tree leaves tree is a special plant in East Nusa Tenggara province with its high nutrient. It grows mostly in the house environment of the congregation of Lahai Roi church, Tofa and it is manufactured only as a kind of vegetable that makes consumers are less interested, but if it is manufactured in different kinds of meals its consumption can get increased. The less understanding in manufacturing marunggai leaves may emerge undelicious smell. This writing is a public service one that is important to train all housewives in Lahai Roi congregation, Tofa to make pinnate leaves wet cakes. The methods used were discussion and training methods of making pinnate leaves wet cakes (like cake, brownie, and tiramisu cakes). The result shows that the percentages of those housewives understanding in making pinnate leaves cakes, such as cake, brownies, and tiramisu cakes are in orderly $97 \%, 95.2 \%$, and 91.7\%. These percentages indicate that the housewives in Lahai Roi congregation, Tofa have a good understanding and they can make pinnate leaves wet cakes. By conducting the training of making pinnate leaves wet cakes in Lahai Roi congregation, Tofa it can increase community interest in consuming pinnate leaves that have high nutrients.
\end{abstract}

\begin{abstract}
Abstrak
Tanaman kelor merupakan salah satu tanaman khas NTT yang mempunyai nilai gizi tinggi. Tanaman ini banyak tumbuh dipekarangan jemaat Lahai Roi Tofa dan hanya diolah menjadi sayuran sehingga kurang diminati namun jika diolah menjadi jenis makanan yang berbeda dan inovatif akan meningkatkan konsumsi kelor. Kurangnya pemahaman dalam mengolah daun kelor akan menghasilkan bau yang kurang sedap. Pengabdian ini penting untuk melatih kaum ibu jemaat Lahai Roi Tofa dalam membuat kue basah kelor. Metode yang digunakan dalam pengabdian ini adalah diskusi dan pelatihan pembuatan kue basah kelor (cake, brownis dan tiramisu). Hasil pengabdian menunjukkan persentasi pemahaman kaum ibu dalam pembuatan kue cake, brownis dan tiramisu kelor berturut-turut adalah 97\%, 95,2\% dan 91,7\%. Hal ini menunjukkan bahwa kaum ibu jemaat Lahai Roi mampu dan memahami pembuatan kue basah kelor. Adanya pelatihan pembuatan kue basah berbahan kelor di jemaat Lahai Roi Tofa dapat meningkatkan minat masyarakat dalam mengkonsumsi daun kelor yang memiliki nilai gizi tinggi.
\end{abstract}

(C) 2021 Author(s)

Keywords: pinnate leaves; wet cakes; brownies; tiramisu.

\section{Pendahuluan}

Propinsi NTT secara klimatologis digolongkan kedalam daerah kering karena disebabkan oleh curah hujan yang relatif rendah dan tidak merata. Meskipun demikian, di wilayah NTT terdapat berbagai jenis tanaman yang sangat

\footnotetext{
* Corresponding author:

E-mail address: johnson_naat@staf.undana.ac.id (Johnson N. Naat)
} 
berkhasiat untuk dibudidayakan sebagai bahan pangan maupun obat-obatan dan makanan yang berguna bagi masyarakat. Salah satu jenis tanaman yang dimaksud adalah tanaman kelor (Moringa Oleifera Lam). Tanaman kelor adalah salah satu tanaman yang sering ditemukan di berbagai tempat dan merupakan tanaman yang paling luar biasa karena kandungan yang terdapat di dalamnya. Faktanya kandungan gizi yang dimiliki tanaman kelor belum diketahui secara luas oleh masyarakat NTT. Padahal, secara ilmiah kelor yang berasal atau hidup di daerah lahan kering di NTT mempunyai kandungan gizi lebih tinggi dari kandungan gizi yang hidup di tempat lain. Namun pengolahannya masih sederhana dan kurang inovatif sehingga kurang disukai padahal apabila diolah secara inovatif dapat meningkatkan nilai gizi.

Daun kelor telah dilaporkan menjadi sumber pangan yang kaya akan $\beta$-karoten, protein, vitamin $C$, kalsium, kalium, dan menjadi sumber makanan yang baik sebagai antioksidan alami, karena adanya berbagai jenis senyawa antioksidan seperti asam askorbat, flafanoid, fenolat, karotenoid (Gopalakrishnan, dkk., 2016; Saputri, dkk, 2019). Selain itu daun kelor juga merupakan sumber vitamin B dan memiliki kandungan lemak yang rendah dibandingkan sardines, vitamin B3 50 kali lebih banyak dibandingkan kacang, vitamin E 4 kali lebih banyak d bandingkan minyak jagung, kalsium 17 kali lebih banyak dibandingkan susu, protein 2 kali lebih banyak dibandingkan susu dan 9 kali lebih banyak dibandingkan yogurt, kalium 15 kali lebih banyak dibandingkan pisang, zat besi 25 kali lebih banyak dibandingkan bayam, serat 5 kali lebih banyak dibandingkan sayuran lainnya yang sangat berguna bagi tubuh manusia (Krisnadi, 2015; Aminah, dkk., 2015; Isnan dan Nurhaedah, 2017; Dani, dkk., 2019). Daun kelor juga telah digunakan untuk mengobati penyakit seperti infeksi kulit, anemia, kecemasan, asma, komedo, darah kotor, bronkitis, kolera dan penyakit lainnya (Yuliani dan Dienina; 2015 dan Purwati, 2019).

Melihat kandungan gizi yang terkandung dalam kelor dan merupakan salah satu tanaman pangan lokal asal NTT dan berdasarkan hasil observasi dan wawancara bahwa tanaman kelor ini hidup sangat banyak dan melimpah di sekitar rumah pekarangan dari warga jemaat Lahai Roi Tofa namun masyarakat hanya mengolahnya dalam bentuk sayur yang direbus. Pengolahan dengan cara direbus dan sederhana tersebut rata-rata tidak disukai oleh anak-anak dan orang dewasa yang mengkonsumsinya. Namun apabila diolah menjadi olahan yang inovatif menjadi jenis makanan yang berbeda maka akan sangat disukai oleh pengkonsumsinya. Sehingga dengan adanya kegiatan pengabdian melalui pelatihan diharapkan pengolahan kelor lebih inovatif menjadi makanan olahan seperti kue basah, diharapkan dapat menambah minat masyarakat dalam mengonsumsi kelor. Kue basah merupakan makanan olahan yang disukai semua kalangan usia, mulai dari anak-anak sampai orang dewasa gemar mengonsumsi kue basah.

Berdasarkan analisis situasi yang telah dipaparkan di atas maka yang menjadi permasalahan dari kaum ibu jemaat Lahai Roi Tofa antara lain: (1). Tanaman kelor banyak tumbuh dan melimpah dipekarangan dan kebun jemaat Lahai Roi Tofa tetapi hanya digunakan sebagai sayur sehingga kurang disukai oleh anak-anak dan orang dewasa yang menkonsumsinya, (2). Mitra belum memiliki pengetahuan tentang khasiat daun kelor sebagai salah satu tanaman khas NTT yang memiliki nilai gizi tinggi, (3). Belum memiliki pengetahuan dan keterampilan tentang pengolahan kue basah kelor dari bahan dasar daun kelor karena tanpa preparasi yang baik akan menghasilkan bau khas yang kurang sedap.

Dari permasalahan yang dikemukakan mitra pada saat observasi dan wawancara, maka solusi dari permasalahan mitra yang dapat dilakukan adalah: (1). Memberikan pemahaman tentang khasiat daun kelor sebagai salah satu tanaman khas NTT yang memiliki nilai gizi tinggi, (2). Memberikan pelatihan pembuatan kue basah kelor (cake, brownis dan tiramisu) dari bahan dasar daun kelor khas NTT. Tujuan yang dicapai dari pengabdian ini adalah kaum ibu yang tergabung di jemaat Lahai Roi Tofa mempunyai pemahaman dan terampil dalam pembuatan kue basah (cake, brownis dan tiramisu) dari bahan dasar daun kelor khas NTT sehingga keluarga, tetangga dan masyarakat berminat dalam mengkonsumsi kelor.

\section{Metode}

Pengabdian ini dilaksanakan pada tanggal 21 Juli 2020 di kaum ibu Jemaat Lahai Roi Tofa-Kupang-Nusa Tenggara Timur. Peserta yang terlibat dalam kegiatan pengabdian ini adalah ibu-ibu yang berjumlah 17 orang. Metode umum kegiatan pengabdian ini berupa ceramah, diskusi, demonstrasi dan pelatihan. Tahapan-tahapan sebagai berikut: (1). Melakukan pertemuan dengan mitra untuk menyampaikan hal-hal yang berkaitan dengan rencana kegiatan, (2). Penyiapan alat dan bahan yang akan digunakan pada saat realisasi kegiatan, (3). Penjelasan tentang khasiat kelor 
sebagai salah satu tanaman khas NTT yang memiliki nilai gizi tinggi, (4). Pelatihan pengolahan kue basah yaitu: cake, brownis dan tiramisu berbahan dasar daun kelor, (5). Melakukan evaluasi terhadap hasil kegiatan. Sebelum dan sesudah pelaksanaan kegiatan peserta diberikan angket untuk diisi. Angket tersebut kemudian dianalisis secara sederhana untuk mengetahui pemahaman peserta kegiatan pengabdian terhadap pelatihan yang diberikan. Teknik analisis data kualitas dalam pengabdian ini melalui langkah-langkah sebagai berikut:

(1) Data hasil respon peserta dalam bentuk huruf dikonversikan menjadi skor dengan menggunakan skala Guttman seperti ditunjukkan pada Tabel 1 di bawah ini:

Tabel 1. Skala Guttman

\begin{tabular}{cc}
\hline Nilai & Skor \\
\hline Ya & 1 \\
Tidak & 0 \\
\hline
\end{tabular}

(Sumber: Sudijono, 2010)

(2) Menghitung skor rata-rata masing-masing pelatihan: pembuatan kue basah cake, brownis dan tiramisu kelor dengan menggunakan rumus dalam pers. (1):

$$
\bar{X}=\frac{\sum x}{n}
$$

Keterangan:

$$
\begin{aligned}
& \bar{X}=\text { skor rata-rata } \\
& \sum \mathbf{x}=\text { jumlah skor } \\
& n=\text { jumlah peserta yang mengisi angket }
\end{aligned}
$$

Selanjutnya mengubah skor rata-rata yang berupa data kualitatif menjadi nilai kuantitatif

(3) Data skor rata-rata masing-masing perlakuan dari keseluruhan aspek dapat diperoleh kemudian dihitung juga dengan persentase pemahaman dengan rumus:

$$
\% \text { pemahaman }=\frac{(\text { Skor total masing-masing jenis kue basah })}{(\text { Skor maksimal ideal jenis kue basah })} \times 100 \%
$$

\section{Hasil dan Pembahasan}

\subsection{Tahap Persiapan}

Pada tahap persiapan, tim pengabdian merencanakan kegiatan yang dilakukan. Yang dilakukan pada tahap persiapkan adalah (a). Tim pengabdian mengadakan rapat untuk membahas hal-hal teknis pada saat kegiatan, (b). Tim bertemu ketua kaum ibu jemaat Lahai Roi Tofa untuk membicarakan hal-hal teknis pada saat kegiatan, (c). Menyiapkan materi untuk dipaparkan pada saat kegiatan dan diskusi, (d). Membeli dan penyiapan alat dan bahan yang akan digunakan pada saat kegiatan. Semuanya dilakukan agar pada saat pelaksanaan kegiatan dapat berjalan dengan baik.

\subsection{Tahap Pelaksanaan}

Kegiatan pengabdian dilaksanakan pada hari selasa tanggal 21 Juli tahun 2020 yang dimulai pukul 08.00-21.00 WITA. Pelaksanaan pengabdian ini dilaksanakan di rumah pelayan ketua majelis jemaat Lahai Roi Tofa. Kegiatan awal pelaksanaan pembukakan dan doa Bersama agar kegiatan pengabdian berjalan lancer, selanjutnya tim membagikan angket untuk diisi oleh peserta. Tujuannya adalah untuk mengetahui sejauh mana pemahaman awal peserta dalam pembuatan kue basah kelor (kue cake, brownis tiramisu) (hasil analisis awal pemahaman peserta dapat di lihat dalam Tabel 2). Selanjutnya penjelasan tentang manfaat kelor dan nilai gizi yang terkandung dalam daun kelor yang hidup di NTT. Pada tahapan ini, tim juga menjelaskan tentang manfaat olahan dari kue basah kelor, tim 
membagikan resep dan prosedur dalam membuat 3 jenis kue basah. Kegiatan selanjutnya yaitu pelatihan pembuatan kue basah kelor. Pelatihan pembuatan kue basah kelor dimulai dari pembuatan kue cake kelor, brownis dan tiramisu. Pelaksanaan kegiatan pelatihan pembuatan kue basah kelor disajikan pada Fig. 1, 2 dan 3.

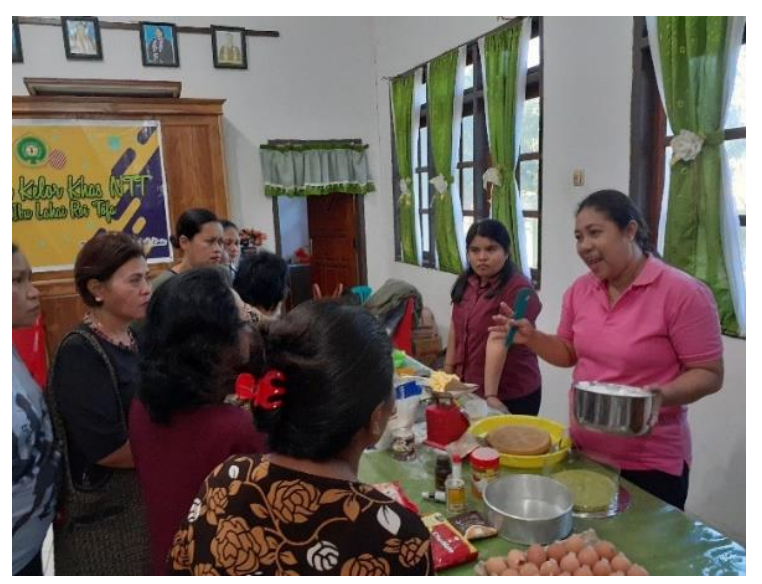

Fig. 1. Penjelasan awal tentang pembuatan kue basah kelor khas NTT

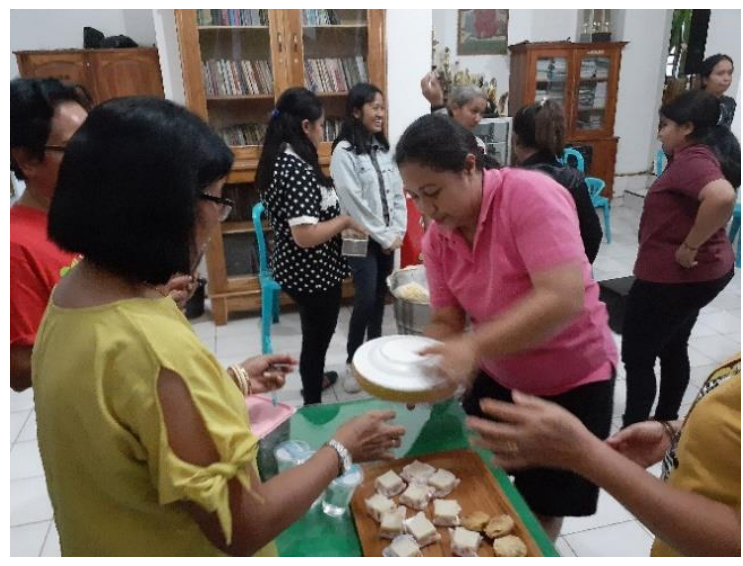

Fig. 2. Pembuatan kue basah brownis kelor khas NTT

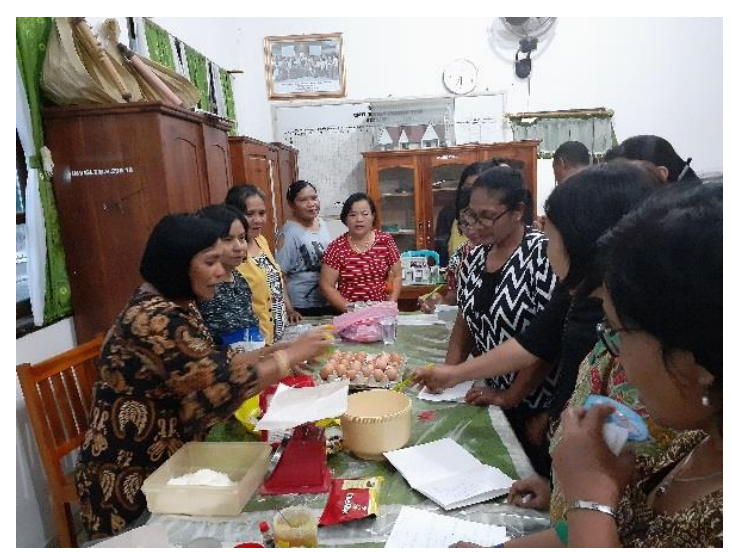

Fig. 3. Pembuatan kue basah tiramisu kelor khas NTT yang dilakukan oleh peserta 
Gambar 1, 2 dan 3 yang ditampilkan terlihat bahwa suasana pada saat pelatihan berjalan dengan baik. Hal ini dikarenakan peserta sangat antusias mengikuti pelatihan dimana tanaman kelor yang hidup disekitar peserta, biasanya daun kelor hanya direbus untuk dijadikan sayur tetapi daun kelor juga dapat diubah kebentuk lain seperti kue basah yang akan sangat diminati oleh peserta dan keluarga di rumah. Untuk mengukur kemampuan dan pemahaman peserta setelah selesai pelatihan pembuatan kue basah kelor khas NTT, tim memberikan angket kepada peserta untuk diisi. Tujuannya adalah untuk mengetahui sejauh mana pemahaman dan kemampuan peserta setelah selesai pelatihan. Hasil pengisian angket selanjutnya diolah dan dianalisis. Hasil analisis awal dan akhir pemahaman peserta dalam pembuatan kue basah kelor disajikan dalam Tabel 2.

Tabel 2. Persentasi pemahaman peserta dalam pembuatan kue basah kelor

\begin{tabular}{lcc}
\hline \multicolumn{1}{c}{ Jenis Kue Basah } & \multicolumn{2}{c}{ Persentasi Pemahaman } \\
& Sebelum $(\%)$ & Sesudah $(\%)$ \\
\hline Cake & 53 & 97,0 \\
Brownis & 48 & 95,2 \\
Tiramisu & 38 & 91,7 \\
\hline
\end{tabular}

Berdasarkan hasil analisis pemahaman peserta kegiatan pengabdian terhadap pemahaman pembuatan kue basah kelor khas NTT dapat dibuat dalam bentuk grafik pada Fig. 4.

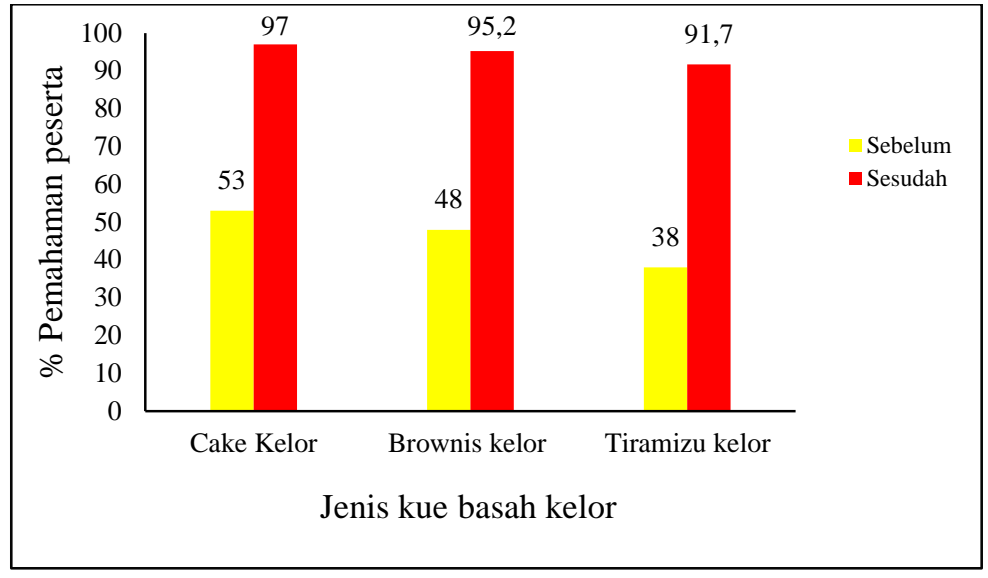

Fig. 4. Grafik pemahaman peserta pembuatan kue basah kelor

Berdasarkan data Tabel 2 dan Fig. 4, hasil analisis menunjukkan bahwa pemahaman peserta kegiatan berjumlah 17 orang dalam pelatihan pembuatan kue basah cake, brownis dan tiramisu berturut turut adalah $97 \%, 95,2 \%$ dan $91,7 \%$. Data persentasi kemampuan awal dibandingkan dengan kemampuan akhir pelatihan pembuatan kue basah kelor khas NTT maka terjadi peningkatan yang cukup signifikan. Rendahnya pemahaman sebelum pelatihan pembuatan dikarenakan preparasi awal dari daun kelor yang kurang diketahui oleh peserta kegiatan dalam pelatihan ini. Sesuai informasi dari peserta bahwa bau/aroma khas dari daun kelor/tepung sangat sulit dihilangkan, karena apabila tidak dipreparasi dengan cara yang benar maka makanan yang dihasilkan memberi aroma yang kurang baik sehingga akan menurunkan minat pengkonsumsinya. Kue basah yang dihasilkan juga memberikan warna khas yaitu warna hijau yang berasal dari warna daun kelor sehingga sangat menarik. Dengan adanya pelatihan ini peserta sudah mengetahui cara dan mampu menghilangkan bau khas dari kelor. Dalam pengabdian ini, peserta sangat antusias dalam mengikuti kegiatan ini. disukai oleh pengkonsumsinya. 


\section{Kesimpulan}

Berdasarkan kegiatan pengabdian yang telah dilakukan maka yang menjadi simpulan dalam kegiatan ini adalah mitra yaitu kaum ibu jemaat Lahai Roi Tofa dapat membuat kue basah (cake, brownis dan tiramisu) khas NTT. Pelatihan yang diberikan sangat membantu kaum ibu Jemaat Lahai Roi dalam pembuatan kue basah karena sejauh ini tanaman kelor hidup dipekarangan jemaat namun tidak dikelola dengan baik menjadi variasi makanan inovatif yang bernilai gizi tinggi. Kaum ibu sangat berterima kasih kepada tim dari Undana dan harapannya kegiatan-kegiatan seperti ini terus dilanjutkan. Dengan adanya pelatihan ini sangat membantu ibu-ibu Jemaat dalam mempersiapkan kue Natal berbahan dasar daun kelor khas NTT. Kaum ibu yang menjadi peserta dalam kegiatan pelatihan pembuatan kue basah kelor khas NTT dapat membuat makanan inovatif dalam bentuk lain sehingga dapat meningkatkan minat konsumsi dari anggota keluarga dan dapat dikembangkan menjadi usaha kecil.

\section{Acknowledgements}

Penulis mengucapkan terima kasih kepada Fakultas Keguruan dan Ilmu Pendidikan Universitas Nusa Cendana (Undana) Kupang atas dukungan finansial dan terima kasih kepada kaum ibu Jemaat Lahai Roi Tofa atas kerjasamanya sehingga kegiatan ini dapat berjalan dan selesai dengan baik.

\section{References}

Aminah, S., Ramdhan, T. dan Yanis, M. (2015). Kandungan Nutrisi dan Sifat Fungsional Tanaman Kelor (Moringa oleifera), Buletin Pertanian Perkotaan, 5 (2), 35-44.

Dani, B. Y. D., Wahidah, B. F., Syaifudin, A. (2019). Etnobotani Tanaman Kelor (Moringa oleifera Lam.) di Desa Kedungbulus Gembong Pati. Al-Hayat: Journal of Biology and Applied Biology, 2(2), 44-52.

Gopalakrishnan, L., Doriya, K. and Kumar, D.S. (2016). Moringa oleifera: A review on nutritive importance and its medicinal application. Journal Food Science and Human Wellness 5 (2016) 49-56.

Isnan, W \& Nurhaedah, M. (2017). Ragam Manfaat Tanaman Kelor (Moringa oleifera Lamk.) Bagi Masyarakat: Makasar, Info Teknis Eboni, 14(1), 63 - 75.

Kementerian Kesehatan RI. (2013). Riset Kesehatan Dasar. Jakarta: Kementerian Kesehatan RI.

Krisnadi, D. (2015). Kelor Super Nutrisi. LSM-Peduli Lingkungan.

Manley, D.J.R. (1998). Tehcnology of Biscuits, Crackers, and Cookies. Ellis Horweed Limited. Chicester.

Purwati. (2019). Evaluasi Daun Kelor (Moringa oleifora) Sebagai Pangan Fungsional, Abdimas, 2(02), 129-135. DOI: http://dx.doi.org/10.24903/jam.v3i2.504.

Saputri, G. R., Tutik., Permatasari, A. I. (2019). Determination of Protein Levels in Young and Old Leaves (Moringa oleifera l.) Leaves using the kjeldahl method, Lampung: Analis Farmasi. 4(2), 108 - 116.

Sudijono, A. (2010). Pengantar Statistika Pendidikan. Raja Grafindo Persada: Jakarta.

Whitely. (1971). Kue basah Manufacture. Applied Science Publishing, Ltd. London.

Yuliana, N. Y., Dienina, D. P. Uji Aktivitas Antioksidan Infusa Daun Kelor (Moringa oleifera, Lamk) Dengan Metode 1,1- diphenyl-2-picrylhydrazyl (DPPH). Jurnal Info Kesehatan, 14(2), 1060-1082. 